\title{
STUDIES ON SYRPHID FLIES IN THE MUSEUM OF COMPARATIVE ZOÖLOGY ${ }^{1}$
}

\author{
By Frank M. Hull \\ University of Mississippi
}

This study presents the descriptions of additional new species of Syrphid flies in the collections of the Museum of Comparative Zoölogy of Harvard University and represents a continuation of earlier studies. Again I wish to thank Professor Nathan Banks for facilities of study extended to me.

\section{Syrphus graptus $\mathrm{n}$. sp.}

Male. Length $11.5 \mathrm{~mm}$.; wing $10.6 \mathrm{~mm}$. Head: eyes bare, touching for a considerable distance; the middle of the posterior margins are gently excavated, the vertical triangle is brownishyellow pollinose, the occipital pile wholly golden yellow; the front, face and cheeks are pale yellow, the upper face and remainder of face except the broad round central tubercle are covered with dense, golden pollen, more shining upon the face than upon the front. There is also on the front a large, circular, polished, shining bare area; from this area there runs upward a vertical, slender, brownish streak, not however, reaching to the point of contact with the eyes. Just above each antenna is a conspicuous shining black spot. Antennæ wholly pale orange, the base of the arista concolorous, its rather long, apical threefifths black. Pile of front long, erect and like that of the face pale and confined to a pollinose area. Thorax: dark, shining golden-

1 Published with the aid of a grant from the Museum of Comparative Zoölogy at Harvard College. Earlier articles in this series, dealing with the Syrphids in the Museum of Comparative Zoölogy, are as follows:

I. New Species of Exotic Syrphid Flies. Psyche, xliv, pp. 12-31; pl. 2 (1937).

II. Descriptions of Some New Species of Syrphidæ. Psyche, xlviii, pp. 149-164, plate $\mathrm{x}(1941)$.

III. Some Flies of the Genus Volucella. Proc. New England Zoöl. Club, vol. xix, pp. 93-98 (1942).

IV. Some Flies of the Genus Mesogramma. Proc. New England Zoöl. Club, vol. $\mathrm{xx}$, pp. $17-24$ (1942).

V. New Species of Syrphidæ from the Neotropical Region. Psyche, xlix, pp. 84107 (1943). 
brown with still darker vittæ as follows: a pair of narrowly separated, median vittæ slightly diverging posteriorly, the posterior ends pointed but rounded on the medial surface, running nearly half-way down that part of the mesonotum behind the suture; moreover, rather widely separated from the median pair, is the outlying pair of wider vittæ, narrowly interrupted at the suture; their posterior section of which is wide but which becomes slender before it stops almost at the scutellum. Between each of the vittæ and narrowly enclosing them even at their posterior ends and including the whole of the outer lateral margin of the thorax the area is covered with light yellowish-brown, almost golden pollen; thus a large, broad, posterior semicircle lying in front of the scutellum is left bare. Pile of dorsum of the thorax and of scutellum and of pleuræ quite erect, wholly pale with a shining silky yellow luster; it is especially long just before the mesonotal suture on the mesopleuræ and the scutellum. Abdomen: elongate, slenderly oval, widest at the end of the third segment, very little less wide basally or at the end of the fourth segment, its greatest width not quite equal to that of the thorax; second and third segments a little longer than the fourth and fifth; fourth segment as long as its own basal width; the fifth segment is a truncated equilateral triangle. Abdomen shallowly convex, non emarginate with the ground color wholly a light rusty red or orange-brown, largely opaque but more shining on the posterior margins and on the narrow basal margins of at least the posterior segments. There is a conspicuous though not wide, transverse, uniform black band across the posterior margin of the second segment and another one about the same width similarly placed on the third segment. On the fourth segment there is a quite subapical, transverse fascia narrow towards the middle, as it nears the midline turning sharply upward as a sharp-pointed wedge of black that reaches quite to the midpoint; on its outer lateral point it turns down sharply to reach the posterior corners of the segment. On the anterior part of the fourth segment some distance from the base there is a slightly oblique slender fascia, its inner end pointed and directed towards the midline of the base; towards the base the inner ends are separated by three times their width. On the anterior half of the third segment about the same distance from the base, are a similar pair of slightly oblique stripes separated by less than twice their width. Legs: almost wholly light yellow, the hind tibiæ and tarsi brownish-yellow due perhaps to 
the fact that their pile is dark brown whereas elsewhere, except upon the apical two-fifths of the hind femora, the pile is pale. Wings: elongate, nearly hyaline, whole of the stigmal cell light brown, the sinuosity of the third vein very slight, the subapical cross vein long, nearly straight, sharply though slightly bent back a short distance from its apex.

Holotype. No. 23796, one male, Sozan, Formosa, June 30, 1934. L. Grissett collector.

\section{Syrphus ochreolinea $\mathrm{n}$. sp.}

Related to orientalis $\mathrm{H}$. B. from which it differs in abdominal pattern, etc.

Female. Length $7.5 \mathrm{~mm}$.; wing $7.5 \mathrm{~mm}$. Head: shining metallic black over the vertex, the upper third of the occiput black with brassy-brown pubescence, the lower part greyish white pollinose; all of the occipital pile is long and yellowish white. The front is shallowly concave with a broad band of greyish-brown pollen across the middle which is from either side directed a little diagonally downwards. The band is of uniform width on a shining black background. Face shining black with a yellowish-brown, inverted V running from base of antennæ towards the eye margins, ending opposite the tubercle, its margins diffuse. The whole of the face except the prominent tubercle is whitish pubescent; the shining black cheeks are also whitish pubescent. Pile of face almost wholly pale; with a few black hairs along the eye margins on the upper part of the face; the pile of the front and vertex is long, erect and black. Eyes rather thickly long white pilose. Antennæ black, the third joint large, suborbicular with reddishbrown pubescence. Thorax: shining greenish-black with long, thick, erect, pale pile. Scutellum greenish-black, somewhat brownish on the posterior half and dark brownish pollinose; the pile on its disc is pale, along its margin is a double row of very slender, long black bristles. Squamæ whitish with yellow fringe, its surface without pile. Abdomen: broadly oval, the first and second segments somewhat flattened, the lateral margin of the abdomen slightly curled over but not emarginate. First segment metallic black, the second shining black with a pair of melanic spots obscurely reddish, small, oval and quite widely separated by at least twice their length. Third segment with a pair of subbasal, light brown transverse spots, each end rounded, set well back from the lateral margin, placed horizontally and separated 
by almost the length of one spot. Remainder of the segment shining black. Fourth segment quite similar to the third, the spots barely less wide. The fifth is segment wholly shining black its anterior corners somewhat brownish. Pile of the abdomen long and pale upon the sides of the first and second segment, shorter but pale and erect along sides of the third and fourth segments; the pile of the third and fourth segments is broadly through their middles sparse, flat appressed and chiefly black. Pile of fifth segment long and largely black. Legs: all of the femora black, their extreme apices brownish. Anterior tibiæ, middle tibiæ, and hind tibiæ except its extreme base, dark brown; all of the taris blackish. Pile of femora chiefly pale. Wings: pale brownish, the stigmal cell wholly dark brown; subapical cross vein sinuous.

Holotype: No. 23800, one female, Nikko, Japan, April 22, 1934, L. Grissett, collector.

This fly traces to orientalis H. B. in Shiraki's key.

\section{Syrphus convexigaster $\mathrm{n}$. sp.}

Related to orientalis $\mathrm{H}$. B. from which it differs in abdominal pattern.

Female. Length $9.15 \mathrm{~mm}$; wing $8.8 \mathrm{~mm}$. Head: upper part of occiput and vertex and front shining black, polished, black pilose. A broad, transverse, broadly interrupted fascia of goldenbrown pollen lies across the quite concave lower portion of the front; its anterior margin is concave; the pollinose area is drawn out along the eye margins until it is opposite the antennæ. Face extensively light brownish-yellow and yellowish pubescent on either side from eye margin to the base of the conspicuous shining black tubercle. The yellow of each side is connected beneath the antennæ and at the eye margins about the middle of the face this yellow area leaves the eye margins and drops nearly vertically down the face, almost to the ventral angle of the oral margin; thus a wide, black middle stripe is left upon the face which tapers acutely to a point beneath the antennæ and which diverges on either side along the oral margin and connects with the black of the cheeks. Facial pile erect, sparse and black throughout; the oral margin, the extreme posterior part of the face and the cheeks also light pubescent. Thorax: black in color, the details obscured by grease; its pile is erect and long, though sparse and wholly pale. Pile of pleuræ long and shining yellowish. Scutellum yel- 
low, the surface is greasy, with abundant very long fine bristles in several rows on the edge of and before the margin. The sparse ventral fringe is black. Squamæ dark brown, the lower lobe bare; the metasternum pubescent. Abdomen: broadly oval, much wider than the thorax, rather convex, the first segment dark shining brown, somewhat metallic on the sides, the remainder of the abdomen shining black, sharply marked with yellow bands as follows: a pair of broad, clear yellow bands on the basal half of the second segment, their inner ends rounded, and separated by a little more than their width and removed from the base of the segment by a little less than their width; their outer ends are diagonally, rounded-truncate and fail by half their width to reach the margin. On the third segment near the midline, narrowly removed from the base, their inner ends rounded, are a pair of spots that, after a short distance, are slightly narrowed and proceed towards the lateral margin which they narrowly fail to reach. Over most of their length except on their medial third they are removed from the base by at least their own width and they are separated in the middle by at least their narrowest width. Their outer ends are subtruncate. On the fourth segment there are a pair of similar bands almost as large and of the same general shape; they are slightly narrower, their inner ends almost touch the base and their later ends again fail to reach the margin. On the fifth segment there are a pair of small, oval, subbasal, yellow spots the medial ends more pointed; the slender, posterior margin of the fourth and fifth segments, except at the sides are yellowish. The sides of the abdomen are quite emarginate. The pile of the abdomen is pale yellow along the margins as far as the end of the third segment, over the yellow spots and to a varying extent beyond it, but the greater part of the pile of the abdomen, especially upon the third and fourth segments is short, subappressed and black; upon the fifth segment it is long and black. Legs: femora black except upon the apical fifth and with the hind femora upon the apical sixth. Hind femora unusually long and slender. Anterior tibiæ and middle tibiæ reddish, more brown upon the distal part, the latter pair diffusely yellow on the basal third. Hind tibiæ brown basally and blackish-brown on the distal three-fourths. Fore and hind tarsi and apical joints of the middle tarsi dark brown; the middle basi tarsi are brownish-yellow. Wings: tinged with pale brown; the stigmal cell very dark brown.

Holotype: No. 23801, one female, Nikko, Japan, July 15, 1931, L. Grissett collector. 
I have carefully compared the present fly with Shiraki's descriptions of Japanese species and I fail to identify it with any of them.

\section{Epistrophe funeralia n. sp.}

Much smaller and unrelated by pattern, etc., to the few known species.

Male. Length $9.2 \mathrm{~mm}$; wing $8 \mathrm{~mm}$. Head: eyes touching for a considerable distance, bare, broadly excavated in the middle on the posterior margin; the posterior occiput is grey pollinose and silvery pilose, the pile becoming black towards the vertex. Vertical triangle small, brownish-black, feebly shining, black pilose. Front broadly opaque, brownish-black, feebly shining just before either antennæ; the front is narrowly light brownish-orange along the eye margins, this area expanding opposite the antennæ into the pale broadly yellow sides of the face. The front is extensively bare above the antennæ; it is long, erect, black pilose on the upper half, shorter black pilose in the yellow margins along the eyes. Pile of face black, sparse, submarginal, confined to the anterior half of the yellow stripe. Face produced forward well beyond the base of the antennæ with a strong, convex tubercle deeply concave beneath the antennæ. Face widely shining black in the middle, roughly about one-half of the facial width being black. All of the anterior parts of the cheeks and the posterior part of the occiput below light yellow, obscurely brownish between. Antennæ widely separated, the first joint black, the second joint very dark basally, the third and the outer part of the second joint light orange; the third joint broadly infuscated above. The arista is short, thick, dark in color, the tip black. Thorax: dark brown, feebly shining on the anterior part, more polished posteriorly; the humeri, a spot on the sides before the suture and post calli obscurely yellowish-brown. The pleuræ are metallic brassy and anteriorly they are silvery over the metapleuræ, pteropleuræ and hypopleuræ. Scutellum large, evenly rounded, colored like the thorax except that on either side there is an oval, apically separated, large diagonal but quite obscure and diffuse yellowish-brown spot. Pile of thorax erect, chiefly light brown on the dorsum, longer and black upon the disc of the scutellum where it is sparse; the long ventral fringe of the scutellum is golden-brown. Abdomen: slender, the sides almost parallel, tapering a little posteriorly, chiefly deep opaque black in ground color, the narrow posterior margins of second, wider ones of third 
and fourth wholly shining black, sides of abdomen not emarginate. The sides of first segment with a large, dull yellowish spot; on either side of the second segment and broadly separated in the middle is a large roughly triangular clear opaque yellow, sharply delimited spot, all of the corners of which are rounded, and which does not reach the side margins. On the third segment is a similar spot of the same size, narrowly separated, more oval, rather pointed on its medial ends and pear-shaped. Fourth segment with a pair of spots similar to that of third, almost connected across their somewhat wider medial ends. Fifth segment with a pair of smaller subbasal spots narrowly connected basally. The spots of the third, fourth and fifth segments are more brownishorange; the pile of the abdomen is pale upon the pale spots of the second and third segments, upon the base and sides of second segment and basal half of third segment; elsewhere it is semiappressed and black. Legs: basal half of anterior, all but the apex of the middle and the whole of the slender hind femora moderately shining black. Apices of the anterior four femora and narrow bases of the four front tibiæ light yellowish-brown. Remainder of anterior four tibiæ dark brown and the whole of the posterior tibiæ black. All of the tarsi dark brown and the whole of the posterior tibiæ black. All of the tarsi dark brown. Pile of the legs, except upon the extreme bases of the femora, black. Wings: strongly tinged with brown, a little more so along the anterior outer half, but everywhere diffuse; the stigmal cell the darkest of all; no stigmal cross vein present. Subapical cross vein almost straight with no sinuosity, with a slight inward bend just past its base and a slight recurrent turn just before the end; however, it joins the third longitudinal vein rectangularly.

Holotype: No. 23787, one male, New Castle, Jamaica, E. B. Bryant, Feb. 16-20.

\section{Rhysops quadrimaculata $\mathrm{n}$. $\mathrm{sp}$.}

Not closely related to any known species of Rhysops; distinguished by the quadrate spots.

Male. Length $6.5 \mathrm{~mm}$; wing $6 \mathrm{~mm}$. Head: large, the eyes touching for a considerable distance, the vertical triangle small, the occiput not protruding beyond the eyes on the upper third. The front is shining bluish-black, grey dusted on the upper half and with a narrow thin line of greyish-white pubescence running down the eye margin which expands anteriorly into a small, tri- 
angular spot on the upper part of the face and again on the lower part of the face opposite the tubercle. The face in ground color is brilliantly shining, metallic black, with perhaps a faint bluish luster. On either side of the midline there is a prominent, ventrally connected, violet stripe, its margin golden inside and out. These stripes are rather widely separated over most of their length; their outer margins are lined by a thin stripe of whitish pubescence. Lower half of face sparsely white pubescent and diagonally striate opposite the tubercle; the middle of the face is cut by four shallow grooves, the outer ones less distinct; the profile of face above the low tubercle is perfectly straight. The first and second joints of antennæ are nearly equal in length; light brownish-yellow; third joint missing. The eyes are bare. Pile of face and front light brownish-yellow, of the vertex darker. Thorax: very convex, shining metallic black; seen from behind there are a pair of brownish, pollinose, median vittæ which run half-way down the posterior part of the mesonotum. There are suggestions of a fourth pair of such vittæ lying some distance from the others on the lateral part of the mesonotum. There is a low but well developed, rounded bump in the middle of the anterior lateral corners of the thorax lying diagonally from the humeri. Squamæ dark brown with dark brown fringe; halteres pale. Scutellum broadly rounded, brilliantly metallic, with two or three subterminal, transverse, faint, ripple-like depressions. Pile of thorax and scutellum pale, the ventral fringe long. $A b$ domen: long and slender, rather flattened, sides almost parallel, end of the third segment barely wider than base of the abdomen. First segment shining metallic black, second shining on the basal two-fifths with a brassy or golden-brown appearance; opaque, dark sepia-brown on almost all of the remaining segments and quite to their posterior margin. Located near the base upon the sides of the second segment, not reaching the anterior corners and covering about one-half the length of the segment there is a shallow, diffuse, brownish-yellow spot; in some specimens it extends inward for a greater distance. Third segment with a pair of large, square, light brownish-yellow spots occupying the base, the entire anterior corners and the sides for one-half the length of the segment; their medial surfaces are just a little cut-away and diminished on their posterior surfaces; remainder of this segment opaque, dark sepia. Fourth segment with a pair of similar spots, slightly smaller, barely darker, and a very little closer together; 
remainder of that segment shining black. The pile upon the abdomen seems to be practically absent on the third and fourth segments, though whether this is due to denudation I cannot ascertain. The sparse lateral pile of the second segment is pale. Legs: almost wholly pale brownish-yellow; the narrow apices of the hind tibiæ and the hind femora, a more obscure subbasal hind tibial band and the last two or three tarsal joints of all of the legs dark brown. Wings: very lightly tinged with brown; whole stigmal cell brown and the apical margin of the wing to just past the end of the third vein marginate with brown giving the impression of an elongate brown spot.

Holotype: No. 23785, one male. Cuba, Wright, and one paratype.

\section{Baccha cubana n. sp.}

Related distantly to the lineata group; distinguished by the anchor-shaped abdominal pattern.

Female. Length $7.5 \mathrm{~mm}$; wing $7 \mathrm{~mm}$. Head: hemispherical, much wider than the thorax, the eyes large, bare, their posterior margins only slightly excavated. The occiput, except at the extreme ventral part, the vertex to just before the ocelli, obscurely shining black; vertical triangle quite narrow, lateral ocellus prac-tically touching eye margin, the ocelli set fairly well forward. Front, long widening to four times its width across ocelli with a conspicuous round black spot just above antennæ; front except for this spot, and the face obscurely shining deep yellow, a little paler on the sides. Face with a low tubercle, almost straight and vertical front tubercle to antennæ, but below the tubercle it retreats rapidly the short distance from the oral margin; there is a shallow concavity between epistoma and tubercle. Cheeks small and wholly yellow. Antennæ short, third joint a little longer than wide, the first joint almost hidden; color of the antennæ light orange, the third joint narrowly brownish above; arista blackish, basally thickened. Thorax: mesonotum broadly shining black; the shining yellow of the wide lateral margin of the thorax narrowly follows the suture inwardly on either side for a short distance. Pleuræ and scutellum wholly light brownish-yellow, the latter with a pair of black, short, apical bristles and just a few short black hairs on the disc. I can discern one or two tiny black hairs that may constitute a ventral fringe. Fringe may be absent. Squamæ light yellow halteres yellowish with a brownish knob. 
Abdomen: elongate, slender, but considerably flattened, the sides posteriorly curved over narrowly along their edges. First segment short, yellow, broadly brownish across the middle; second segment barely longer than the third; third and fourth equal; fifth segment square; the second segment is almost twice as long as wide; the fourth segment just about a half again as long as wide. Second segment brown with a pair of large, oblong, brownish-orange spots well separated from the middle, anterior and posterior ends rounded, reaching the margin and on one side reaching the posterior corner. Third segment brownish-orange except as follows. a prominent median stripe the full length expanded suddenly near the apex into a marginal fascia; this fascia narrowly connects towards the side with a posterior-lateral, acute triangle of brown, produced as far forward as a distance equal two-fifths the length of the segment; the outer margin of this acute triangle is oblique. The fourth segment has a very similar pattern except that posteriorly the middle stripe reaches the apex of the segment; its lateral expansion is more or less obsolescent and the posterio-lateral acute brown triangles are well developed, no wider than these of the third segment but reach forward just past the middle of the segment. Fifth segment quite similar to the fourth in every respect except that it is smaller and that the posterio-lateral triangles are merely elongated vittæ reaching the same proportion of the segment. Legs: the legs seem to be wholly light yellow, basal half of the hind tibiæ barely darker because the pile appears to be darker. The pile is chiefly pale golden but on the hind femora and basal half of its tibiæ it is largely but not entirely brown. Wings: pale brownish; diffusely darker brown throughout the subcostal marginal cell and the apex of the submarginal cell; subapical cross vein rather sinuous, joining the third vein at right angles.

Holotype: No. 23784, one female. Soledad, Cuba, Feb. 27th, 1926, George Salt.

\section{Baccha ochreolinea n. sp.}

Related to cultrata Austen; it is characterized by the broad abdomen and interrupted yellow fascia of the third abdominal segment, etc.

Female. Length about $8 \mathrm{~mm}$; wing $7.5 \mathrm{~mm}$. Head: hemispherical, deeply excavated in the middle; vertex narrow, dark, obscurely shining brown, continued forward as a wedge of slightly 
decreasing width to the middle of the face. There is a tiny black spot above the antennæ, quadrate, connected to the slightly larger, deep lunule of brown above it. Ground color of front, face and cheeks pale yellow, the former slightly brown in the middle, the pile of the occiput on the upper fifth of vertex, front and upper part of face erect and black, a very little pale pile on either side of the tubercle. Occiput except immediately behind the ocelli pale yellowish pollinose. Tubercle small, extending barely beyond the base of the antennæ; profile almost straight above the tubercle, retreating sharply below it; the cheeks small. Antennæ light orange, the third joint broadly dark on the dorsal half and the apex and scarcely longer than wide; pile of the basal joints black; arista black. Thorax: dark golden-sepia with a pair of obscure, yellowish-brown pollinose vittæ extending somewhat past the mesonotal suture and between it a narrow line of the same color. Lateral margins of the thorax broadly yellow; pleuræ, except propleuræ, lower sternopleuræ, lower pteropleuræ, hypo and metapleuræ pale yellow, otherwise dark brown. Scutellum wholly light brownish-yellow with several black bristles on the margin and five or six black hairs on its disc; I cannot discern any ventral pile. Abdomen: broadly oval, quite flattened, the first segment yellow on the sides with bristly black pile broadly brown across the middle. Second segment almost a third again as wide posteriorly as anteriorly; shining dark brown in color and somewhat lighter along the sides with a conspicuous, transverse fascia across the middle of uniform width, slightly convex, not quite reaching the side margin. Third segment barely wider posteriorly, of similar ground color; it has a slender, basal, yellow fascia not reaching the side margins and a quite broad fascia across the middle; it is broadly interrupted in the middle anteriorly narrowly from its posterior medial corners and on each side in the middle slightly concave. This fascia does not quite reach the lateral margin. Fourth segment with blackish markings on a light yellowish-brown background as follows; the entire narrow lateral margins; on either side from the posterior margin a large triangle is directed towards the base of the segment and reaches two-thirds of its length, its medial surface is more or less straight and its outer surface approximately straight but diagonal. There is a broad, median vitta rounded off anteriorly, a little wider anteriorly and just reaching the base of the segment. The median vitta and the lateral triangles are narrowly connected along the 
posterior margin. The anterior corners of the segment are dark brown and connected with the brown lateral margins. Fifth segment marked in an exactly similar way, the lateral triangles more slender but reaching almost to the base of the segment and not connected with the somewhat more slender median stripe which latter is concave on each lateral surface; the anterio-lateral corners of brown are absent; sixth segment with three median vittæ of brown. Pile of abdomen wholly flat-appressed and black. Fourth segment about twice as wide as long, the third segment barely longer, the fifth barely shorter, the third barely shorter than the second. Legs: anterior and middle pair wholly pale yellow, pale pilose, the middle femora with a posterior row of long dark hair. Posterior femora light brown, apex yellow with a wide, dark brown, subapical annulus; almost the whole of its pile is black. Hind tibiæ except for the very narrow base wholly dark brown, blackish pilose. Hind tarsi wholly yellow. Wings: very darkly tinged with brown, rather deep, and elongate oval; the alulæ is small, the subapical cross vein rather sigmoid.

Holotype: No. 23802, one female. Canal Zone, Barro Colorado, July 24, 1924, N. Banks collector.

\section{Salpingogaster panamana $\mathrm{n}$. sp.}

Related to cothurnatus Bigot; it differs in the red and yellow pleuræ and yellowish brown tarsi.

Male. Length $12.5 \mathrm{~mm}$.; wing $9 \mathrm{~mm}$. Head: vertical triangle shining blackish, the front narrowly yellow upon the sides, broadly brownish-black in the middle, not especially protuberant. Face pale yellow and shining with short, pale yellow shining hair, rather sparse. There is no black or dark facial stripe. Antennæ light brown throughout, without any suggestion of yellow or orange. Occiput black, sparsely pale pilose. Thorax: broadly dark brown over the mesonotum which is somewhat greasy and in consequence the arrangement of the pollen or possible vittæ is obscured. Nevertheless the thorax appears to have been broadly greyish pubescence throughout the middle; it was probably vittate. The humeri, a stripe along the sides as far as the suture only, the post calli and the whole of the scutellum except for a brown transverse band, pale yellow. Pleuræ reddish brown with a broad stripe on the posterior half of the mesopleuræ and propleuræ, anterior portion of the pteropleuræ and the greater part of the sternopleuræ pale yellow. There is a second small 
wedge-shaped yellow spot or stripe upon the metapleuræ. $A b$ domen: chiefly yellowish, the first segment wholly yellow, second segment light brownish-yellow throughout with a slender but inconspicuous scarcely darker brownish line down the middle. Third segment yellow laterally on the basal two-fifths; in the middle and upon the entire remainder of the segment light reddish-brown. Whole of the fourth segment and the hypopygium reddish-brown. The hypopygium seen from above is bulbous at the base and drawn out into an abrupt point, therefore the hypopygium proper viewed from above looks somewhat like an acutely pointed equilateral triangle. The pile of the abdomen is pale yellowish upon the first and second segments; on the remainder of the segments it is brown but not black. The abdomen is rather slender in shape. Legs: anterior legs almost wholly light yellow; last four joints of tarsi pale brown, the middle pair exactly the same; hind femora brownish on the basal fifth and obscurely brownish before the apex. Hind tarsi brown, appearing darker because of the black pile, the apical joint yellow. Hind femora ventrally with sparse black spinules throughout its whole length which near the apex are arranged in a single row on each side. Wings: upon the costal, and upon the subcostal and marginal cells, clear yellow as far as the end of the costal cell. The outer or stigmal portion of the subcostal cell and the outer part of the marginal cell sharply dark brown, the color extended narrowly along the apical margin of the submarginal cell. The brown of the subcostal cell is definitely darker than that of the marginal cell. Also the fifth longitudinal vein throughout its posterior section and base is margined with brown. Subapical cross vein strongly sigmoid; loop of third vein deep, rising vertically.

Holotype: No. 23803, one male. Bella Vista, Panama, August $8,1924, \mathrm{~N}$. Banks collector.

This species is somewhat similar to cothurnatus Bigot from which it appears to differ in a number of particulars. It is considerably smaller and the tarsi are pale brown, tending rather to be yellowish instead of black as described by Bigot. Apparently the pleuræ of cothurnatus are black whereas here they are reddish, with a single large yellow and a single small yellow stripe. The abdomen in this species is more extensively yellowish, in cothurnatus reddish with the posterior borders brown. I have a specimen from Panama quite different from the present specimen 
and which more closely agrees in size and black pleuræ with the description of cothurnatus and is so close to the present species in type of wing pattern and general coloration and triangularly pointed hypopygium that the general similarity between the two is remarkable. Nevertheless they are abundantly different in many respects. It is worth noting that the description of cothurnatus by Sack in the revision of the genus disagrees from Bigot's description in the particulars of the color of the tarsi. Sack describes the hind tarsi as wholly yellow and the anterior tarsi yellowish with the three last tarsal joints black.

\section{Microdon aureus $\mathrm{n}$. sp.}

Related distantly to beebei Curran, but characterized by its golden pile.

Female. Length $19.5 \mathrm{~mm}$. which includes the $4 \mathrm{~mm}$. antennæ; wing $11.5 \mathrm{~mm}$. Head: vertex and upper occiput dark, shining, metallic green, becoming more or less opaque black on a transverse band in front of the scutellum from eye to eye. Front very shallowly concave, the antennæ situated high upon the head with very short front. Pile along the upper part of the occiput exclusive of post vertex, very short, appressed, brassy yellow. Pile behind vertex longer, upright, black; immediately about the ocelli it is short, appressed, black. Upon the front there is a black pilose area upon an opaque black band; just in front of the opaque black band is a transverse band of pale brassy pile, its anterior border directed forward, its posterior border directed backward and culminating in each eye margin in a fan-like tuft of flat-lying, similarly colored pile that is directed towards the mid-line. Pile of face, except for a black area on the eye margins of the lowest part of the front everywhere pale golden, short, flat-lying and wiry. A tuft of black hairs is directed downward over the middle of the epistoma. There is a vertical band of pale pile on either side of the mid-line of the face, a transverse band from the eye margin to the anterior margin of the epistoma; there is also a rough, rounded area below the antennæ on each side, which is covered by a downward and somewhat obliquely directed area of pile running from the base of antennæ towards the eye margin. Face everywhere shining black except for a mere suggestion of a light colored spot on each side near the middle and near the eye margins. Antennæ elongate, quite slender, the third joint barely longer than the first two, the second joint not quite 
half as long as the first. Basal half of first joint dark reddishbrown, remainder of antennæ black. Labellum of face with a pollinia from an orchid attached to it. Thorax: dull black with purplish and greenish reflections, a very narrow stripe of pale pile along the margin some distance from the edge of the lateral sutures that forms anteriorly a collar of pile back of the head. A broad equilateral prescutellar triangle and the whole of the scutellum is covered with flat, long, backward-directed, thick, brilliant golden pile. The remainder of the mesonotum is covered with appressed, very dense and extremely short black pile; metanotum greenish. Abdomen: elongate, the second segment flattened, barely wider than long, with on its anterior margin a pair of narrowly separated, almost confluent, nearly rectangular, translucent spots; these spots are pale yellowish, unusually hyaline and each spot narrowly reaching the lateral margin in the middle of each side of the segment. Remainder of second segment and of the remaining segments wholly dull black. The abdomen, beyond the second segment, forms a stout, deep, cylindrical, bluntly-pointed, club-shaped body that is everywhere microscopically black and flat-setate. The middle of the first segment has a transverse band of golden appressed pile. Legs: everywhere, except narrowly at the base of the hind femora, black in color. The femora have slight greenish reflections the base of hind femur reddish brown. Pile of legs extremely short and pale, dense and appressed. Wings: with the usual spur vein, which is however, quite obliquely produced forward. Wing rather pointed, the posterior angles of the first and second posterior cells very much rounded. The entire anterior border of the wing dark brown including the costal, subcostal, marginal, submarginal cells, narrowly the posterior side of the third longitudinal vein, the whole of the first basal cell and both margins of the small cross vein and its connection to the fifth longitudinal vein.

Holotype: No. 23807, one female: Jatun Yacu, Rio Naxo, Watershed, 700 meter, Oriente, Ecuador (Wm. C. MacIntyre).

\section{Mixogaster orpheus n. sp.}

Closely related to anthermus Walker but with minor differences in the wing venation.

Female. $12 \mathrm{~mm}$. excluding antennæ; wings $12 \mathrm{~mm}$. Head: vertex, except immediately around the ocelli, occiput, except for a diagonal stripe from the corner of the eyes, and front except for 
a transverse band across in front of the antennæ including the short antennal prominence and a conspicuous round spot just beneath the antennæ, everywhere light brownish yellow; the exceptions noted are brown. The following areas are also brown: an oval spot or stripe diagonal from the corner of the eyes to the back of the occiput in which there is an impressed line, the area immediately around the ocelli, a conspicuous round spot beneath the antennæ all brown. There is a large, transverse spot above the antennæ, including the short but black antennal prominence which is reddish brown and is widely separated from the eye margins. Antennæ light brown; second joint half as long as first, third joint missing; antennal pile dark brown; extreme base of first joint with a black annulus. Face rather conspicuously concave just above the middle with very sparse pale pile. Eyes bare. Thorax: chiefly light brownish-yellow, with a short pair of submedian, slender, brown stripes that are almost fused with a much wider pair of stripes that lie on either side of the thorax and run throughout its length and slightly converge posteriorly and whose anterior lateral ends fill out the entire corners of the thorax behind the humeri, leaving, however, a large yellow spot before the suture. Pleuræ wholly pale, shining yellow, almost bare with a single diagonal reddish stripe from base of wing down to hind coxæ and a brown stripe behind the metapleuræ. Scutellum broadly brown across the disc, the base and the posterior margin yellow; somewhat triangular in shape with rounded apex. Metanotum yellow; humeri yellow; squamæ yellow with a brown margin and fringe; halteres brownish yellow. Abdomen: elongate, quite petiolate; the first and second segments are subcylindrical, fused, narrowest in the middle and not quite as long as the remaining three segments. There is a reddish stripe running from the base of the second segment diagonally down the long second segment to meet the opposite stripe in the middle a short way from the end of the segment; elsewhere the first two segments are shining yellow. The remainder of abdomen is light brown, the posterior third of the third segment uniformly light yellow; pile of abdomen everywhere pale. Legs: wholly light yellow, the apical two-thirds of the hind femora a little darker; pile of legs wholly yellow. Wings: large and long, longer than abdomen, faintly brownish-yellow along the anterior half with stigmal cross vein, very short anterior cross vein and with a practically straight subapical cross vein that joins the third vein approximately at a 
right angle; posterior corners of the first and second posterior cells with well developed spurs.

Holotype: No. 23794, one female. Bartica, British Guiana, August 19, 1901, collection C. W. Johnson.

This fly, which is a true Mixogaster because of the fact that it lacks any spur or vein from the third longitudinal vein into the first posterior cell as well as by its petiolate form, is characterized by its light brownish yellow color and large wings. It was compared at the British Museum by myself with the type of anthermus Walk. and found to be very close to that species differing, however, in particulars of the wing venation. It is also close to anthermus from the Amazon region in other respects, differing in the less developed occiput, the less retreating face and in the presence of the lateral yellow spot anterior to the suture of the thorax, in the absence of a much reduced brown square upon the metanotum and in the isolated brown spot around the ocellus. There are probably other differences but the general pattern coloration in the dried specimens leaves the markings obscure.

\section{Planes proxima $\mathrm{n} . \mathrm{sp}$.}

Related to vagans Wied., the anterior tibiæ are extensively dark brown, the lower part of the face is reddish brown and the abdominal pattern is different.

Female. Length $9.15 \mathrm{~mm}$.; wing $6.8 \mathrm{~mm}$. Head: eyes bare, vertex in front shining bluish-black, the latter with a broad silvery pubescent band from eye to eye which is indented above and below in the midline; almost the whole of the face is covered with pale greyish-white pubescence, worn off a little on either side below the sharp facial carina; ground color of the face metallic black, except that it is obscurely reddish on either side above the oral margin; the face is retreating and in profile very shallowly concave on the lower part. Antennæ elongate, the first and second joints dark brown, the third reddish basally and on the ventral third but otherwise dark greyish-brown; arista long, slender, reddish. Thorax: obscurely shining black, chiefly short pale pilose, with some black pile along the middle behind the suture and more extensive black on the sides behind the suture but beginning to vanish as it reaches the posterior calli. The pile, then before the scutellum is broadly pale, somewhat appressed and more or less directed forward and towards the sides. Seen from behind there are a pair of widely separated, broad, median 
vittæ of pale shining yellow pile which is directed more or less forward. Pile and pubescence of the mesopleuræ whitish; scutellum with a strong brassy cast, faintly impressed rim, its pile about half and half black and pale. Abdomen: elongate, narrowest at the end of the third segment where it is but little less wide than the base of the third segment. Ground color anteriorly very dark brown, almost blackish, becoming more brassy on the fourth segment. First segment shining dark reddish-brown with a strong brassy cast that is quite absent upon the next two segments. On either side of the second segment, widely separated, is a pair of large yellow spots opaque, rectangular, with corners rounded, the anterior lateral corner slightly attenuated, the posterior corners vaguely attenuated, widely separated from the lateral margins. On the third segment there is a pair of similar, smaller, more diffuse and more obscure spots. Pile of fourth segment wholly semiappressed, pale yellow and quite abundant. There are not over three or four black hairs in the middle of this segment. Pile of fifth segment erect and wholly pale. Legs: all of the femora very dark brown almost black with narrow reddish apices; the hind pair with the usual rather extensive thickness; its pile is pale but its ventral spines black, quite long and sharp and beginning quite in the middle of the ventral surface of the femora. Anterior tibiæ blackish-brown upon the apical half dorsally; and ventrally upon the apical two-thirds brown quite to the apex. Middle tibiæ almost wholly yellowish, pale whitish on the basal half, faintly brownish apically, the spines black. Posterior tibiæ quite arcuate, the basal third pale yellow, the remainder dark brown, the apical spur triangular but quite sharp and rather long; the pile is wholly pale except along the whole of the ventral margin there is a narrow dense band of erect black pile. Basal three joints of anterior and middle tarsi wholly pale yellow, their apical and hind tarsi light brown. Wings: lightly tinged with brown, stigmal cell wholly dark brown; there is no spur from the posterior corners of the first and second posterior cell.

Holotype: No. 23791, one female, labelled 'proxima' beneath which is the label - "variety of ejuncida" Loew coll. There is no locality. It is presumably from the West Indies. 


\section{Crepidomyia darlingtoni $\mathrm{n}$. sp.}

Related to tricrepis Shannon but very distinct in the smoky wing apex.

Male. Length $14 \mathrm{~mm}$; wing $10.8 \mathrm{~mm}$. Head: rather short and therefore wide and flat; the eyes are large, conspicuous, bare, the anterior facets slightly enlarged above, touching only a short distance. Vertical triangle obscurely shining black and long, erect black pilose. Upper third of occiput black and black pilose. The whole of the flat front totally obscured by thick, microscopic, brilliant, golden pubescence. Face strongly carinate with a lateral ridge or keel reaching from eye margins of epistoma slightly concave anteriorly along the lateral keels and this broad shallow concave area is covered by pale brassy pubescence forming a broad stripe from the lateral facial strips to the oral margin; remainder of face shining black; facial strips pale pubescent; cheeks shining black. Antennæ black, the third joint with brownish pubescence, about half again as long as the third joint, gradually thickened towards the base, blackish on the basal sixth, remainder white. Thorax: dull black with a brownish tinge due to four very obscure barely discernible vittæ; the inner pair are shorter, more closely separated, but diverging posteriorly, the outer pair reaching to the scutellum. On the extreme anterior edge of the mesonotum lying inside the humerus there is an almost equilateral triangle of pale shining yellow pubescence. Along the dorsal suture, stopping someways from the midline there is a long, slender, marginal stripe of yellowish-brown pubescence; upon its medial ends and anterior side it curves sharply backwards for a little distance. Pile of thorax wholly suberect, black. Scutellum shining black with faintly impressed rim, its discal pile black, its ventral pile thick, long and pale. Abdomen: moderately long but compact, not so wide as thorax, widest at the basal third segment, but scarcely less wide either at base or end of fourth segment; wholly shining black, the first two segments somewhat flattened, the pile everywhere flat-appressed and black except as follows: sides of first segment and broadly over the anterior corners of the second nearly to the end of the segment of erect pale pile; a small, marginal, lateral, subbasal patch of white pile on the third segment and a medio-apical patch on the last segment. Legs: chiefly shining black, the anterior tibiæ distally, greater distal part of the middle tibiæ dark brownish-black. Anterior basal tarsi dark 
brown; two basal, mid-tarsal joints and the hind basal tarsal joints light brown. Hind tibiæ with a short, inconspicuous, ventral apical spur; hind femora considerably thickened in the middle, more slender on the posterior half than on the basal half and all of the thickening confined to the dorsal side of the femora. Hind trochanters with a long spur. Metasternum pubescent; without spur. Wings: strongly tinged with brown on the anteriorapical half, becoming diffuse posteriorly; the color more sharply delimited about the stigma, the point of fusion of the subcosta and at the separation of the first and second longitudinal vein.

Holotype: No. 23789, one male. Mounts north of Imias, Eastern Oriente, Extreme eastern province of Cuba, July 25-28, 1936, 3-4,000 ft. Darlington collector.

I take pleasure in naming this handsome species for Dr. Darlington, who has brought so much interesting material out of the West Indies.

\section{Temnostoma japonicum n. sp.}

Related to bombylans Fabr., but differing in the dark pattern of the wing, the basally black femora, etc.

Male. Length $14 \mathrm{~mm}$.; wing $11 \mathrm{~mm}$. Head: eyes bare, almost touching in the middle. The vertical triangle is obcurely shining black, but only as far as the corner of the eye; the entire occiput is dull, brownish-golden pollinose, narrowly divided in the midline and extending just a little further posteriorward along the eye margin. The lower part of the front golden pubescent except for a prominent, acute, shining black triangle above the antennæ, its apex continued as a narrow line to the narrow black area between the eyes. There is a smaller, impressed black triangle within the larger one. Face shallowly concave below the antennæ, broadly shining black, finely striate in the midline, the midfacial stripe expanding to a large triangular area below the antennæ; elsewhere the face is broadly golden-yellow pubescent, and with only very short, sparse, pale pile upon the lower part of the face in front of the cheeks. Antennæ light orange, the third joint oval after an oblique fashion, its margin rounded. Arista light orange, the cheeks shining black. Front without pile, that of the vertex shining yellowish. Thorax: dull black, scutellum of the same color, the mesonotum with a pair of obscure greyish vittæ set close together that run half of the distance from the suture to the scutellum. There is a conspicuous, laterally widened, 
medially tapered, golden, pollinose stripe lying in front of the transverse suture, broadly interrupted in the middle, but continued over most of the posterior part of the mesopleuræ. There is no trace of pale pollen anterior to the posterior calli, but there is a quite obscure, reddish pollinose spot lying upon the mesonotum at the base of the scutellum. Pile of the anterior half of the thorax short and shining reddish; of the posterior half short reddish with considerable black hair around the middle. Pile of scutellum wholly reddish, of mesopleuræ whitish. Abdomen: elongate, with almost parallel sides, the third segment barely wider than at the end of the second segment and at the end of this segment about as wide as the thorax. Ground color of abdomen black, dull in color, obscurely shining upon the fourth and last half of the third segment and posterior corners of second. Second segment with slightly oblique, much elongated, narrowly connected yellow spots; their lateral ends are rounded and they lie on the basal third of the second segment. Viewed from behind, these spots appear to be completely interrupted. On the third segment there are a pair of similar golden-yellow pollinose spots which are more slender, reach no closer to the lateral margin, but are slightly more pointed laterally and which are narrowly connected in the middle of the medial ends. On the fourth segment there is a transverse, somewhat broader, narrowly subbasal, similar, golden pollinose band shallowly indented in the middle near its lateral ends, turning slightly downward in oblique fashion; its lateral, somewhat pointed ends do not reach the side margins. The spots of the third segment are more transverse than either of the other two. The pile of the whole posterior two-fifths of the third segment except narrowly on the sides is appressed and black; the pile of the third segment is wholly appressed with considerable black pile confined to a central area on the posterior half, elsewhere it is shining reddish. The whole of the pile of the fourth segment is flat appressed and shining reddish. Pollen of the second and third fascia more brownish; that of the second segment pale yellow. Legs: all of femora except their apical third or less black with sparse greyish pollen and wholly pale pile; apices of these light reddish brown. Anterior tibiæ reddish-brown, dark brown upon the anterio-medial surface of the apical half; middle tibiæ wholly light reddish-brown; hind tibiæ similar in color, a little darker upon the medial posterior margin on the apical half. Anterior tarsi wholly black, the last 
joint reddish brown pollinose, middle and hind tarsi wholly pale reddish-brown; pile of hind tibiæ and tarsi and a middle tibiæ and tarsi wholly pale, of the anterior tibiæ and tarsi wholly black except upon the ventral medial margin of the former and ventrally upon the basi tarsi. Wings: broadly reddish-brown upon the anterior half, as far as the posterior margin of the first basal and upon the first posterior cell as far as the posterior margin of the first basal and upon the first posterior cell as far as the end of the vena spuria. Anterior margin of first posterior cell broadly brownish, almost to the apex of the cell. Apical margin of submarginal cell paler. The costal and second basal cell light brownish-yellow. Vena spuria especially dark brown.

Holotype: No. 23798, one male. Nikko, Japan, L. Grissett collector, July 19, 1931.

This specimen I had tentatively determined as T. bombylans Fabr. I now believe that it presents specific differences from that species. It is characterized by the extensively basally black hind femora and the definitely indented and almost interrupted cross band of the abdomen and the strongly reddish pile of the thorax and abdomen.

Temnostoma fumosum n. sp.

Distinct from bombylans Fabr., in the concentration of the dark wing color near the middle of the wing.

Female. Length $14 \mathrm{~mm}$.; wing $12 \mathrm{~mm}$. Head: occiput tumid, together with the vertex bare upon the upper part and shining black; front shining black, especially polished upon the lower half with a short linear stripe of brownish-white pubescence along the eye margin that begins a short distance below the ocelli. There is a trace of a similar spot in the middle of the front; it may be that the front was originally broadly light brownish pubescent. Face shining black, strongly concave on the lower portion, the bottom of the concavity lying at the tip of the antennæ; in this specimen it so happens by accident that the antennæ are folded down and just fit into the concavity. Face covered with a very sparse scattered, whitish pubescence and still more sparse, pale pile. Cheeks shining black. Antennæ large, the first two joints shining, brownish-black; the third is much wider than long with evenly rounded margins, reddish-brown, silvery pubescent. Arista very long and slender, reddish in color. Thorax: moderately shining black, rather convex with appressed pile which is 
chiefly black but is broadly reddish down the midline and again just before the scutellum. There is a narrow obscure line of pale pubescence along the outer portions of the mesonotal suture. Humeri convex, shining black, pale pilose. Scutellum obscurely shining black with some long pale pile and shorter, black, tuberculate, setaceous pile. Abdomen: quite convex, elongate, somewhat oval, widest in the middle of the third segment, the base of the abdomen but little wider than the apex, the abdomen somewhat wider than the thorax at its widest point. Color of abdomen chiefly black, moderately shining. On the second segment there is a pair of linear, very obscure, reddish, almost obsolescent spots; they are widely separated in the middle and do not reach the sides; they are slightly oblique and placed a little before the middle of the segment. If the abdomen is viewed from the front the spots become more evident because they are clothed with thick, pale yellow pubescence. Pile of the posterior three-fourths of the segment appressed and black. On the base and sides of the segment the pile is quite long, erect and whitish. The third segment has a pair of similar, slightly oblique, larger and more evident linear bands which almost reach the side margins and which occupy a natural depression in the abdomen; they are narrowly separated in the mid-line, are reddish in color and are outlined from in front chiefly by thin golden pile and very little pubescence. The fourth segment has a conspicuous, complete, subbasal band running almost to the lateral margin and diverging a little from the basal margin towards the sides. This band is light reddish-brown pollinose but there is some evidence that it may have been golden pollinose originally. It is sparse, golden pilose; elsewhere the third, fourth and fifth segments are shining black and semi-appressed black setate. Legs: femora almost wholly black; only the very narrow apices brown. Hind femora quite slender; fore tibiæ wholly black, its very narrow base excluded; middle and hind tibiæ chiefly black, narrowly brownish apically. Anterior tarsi wholly black. Middle and hind tarsi light reddishbrown on the basal three joints; others dark brown. Wings: with a strong brown spot on the anterior border just past the middle, occupying the region from the costa to the vena spuria and all of the basal part of the marginal cell and the area below this to the vena spuria, extending moreover along the posterior margin of the fourth longitudinal vein for a short distance on the apical side of the small cross vein, extending off on both sides of the 
third longitudinal vein but growing fainter apically, extending broadly along both sides of the second longitudinal vein all the way to the costa and filling the stigmal cell.

Holotype: No. 23799, one female. Nikko, Japan, July 10, 1931. L. Grissett, collector. 

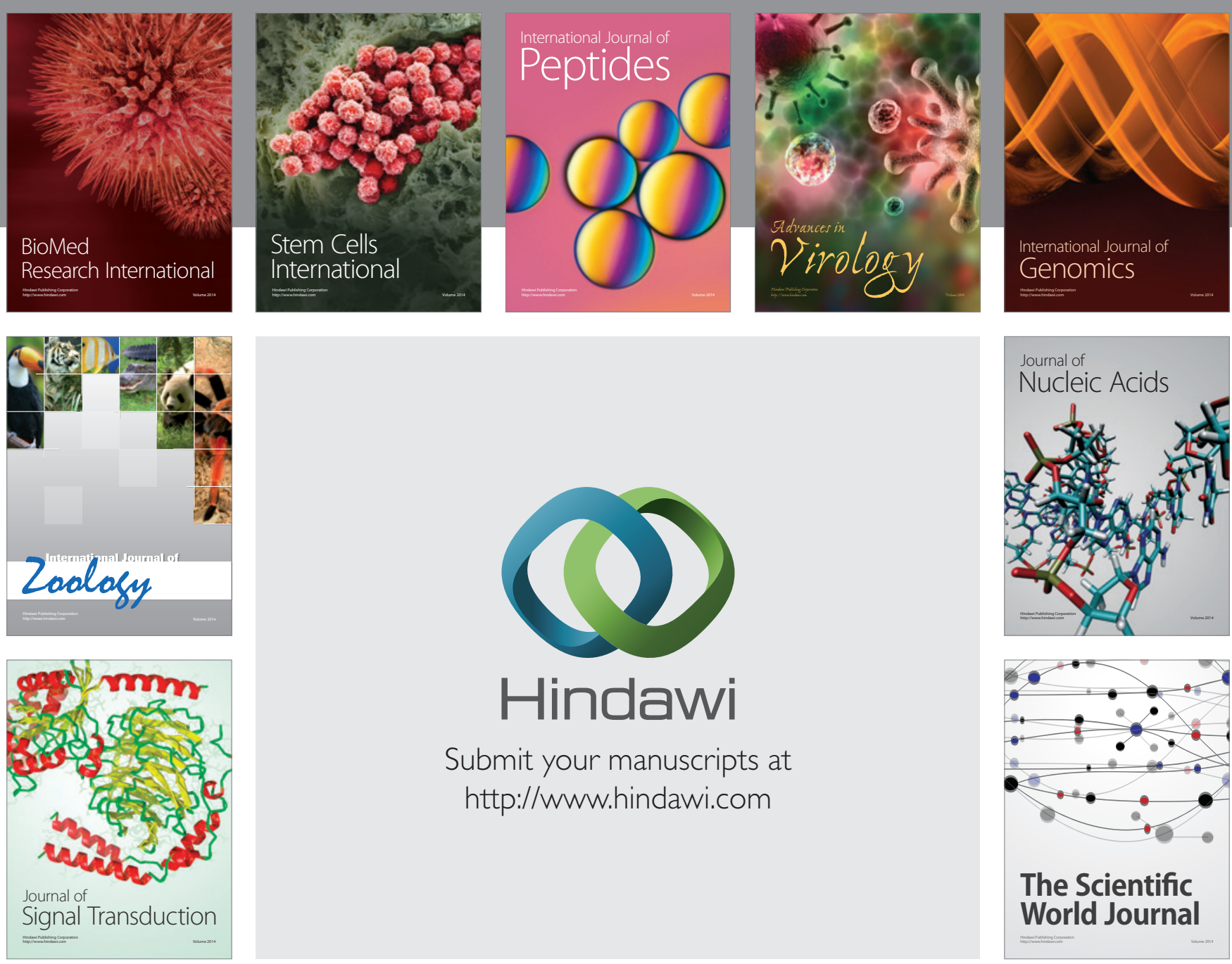

Submit your manuscripts at

http://www.hindawi.com
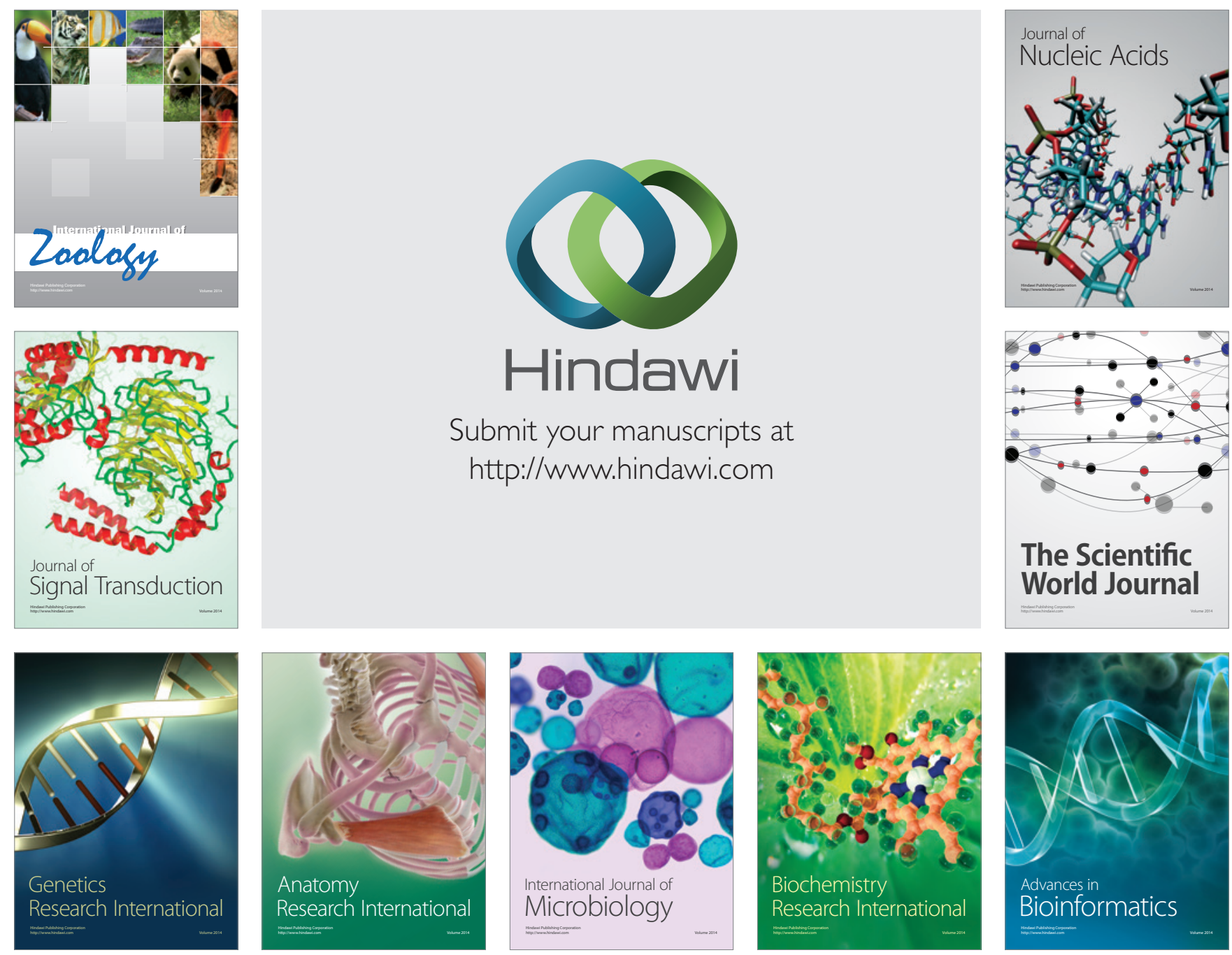

The Scientific World Journal
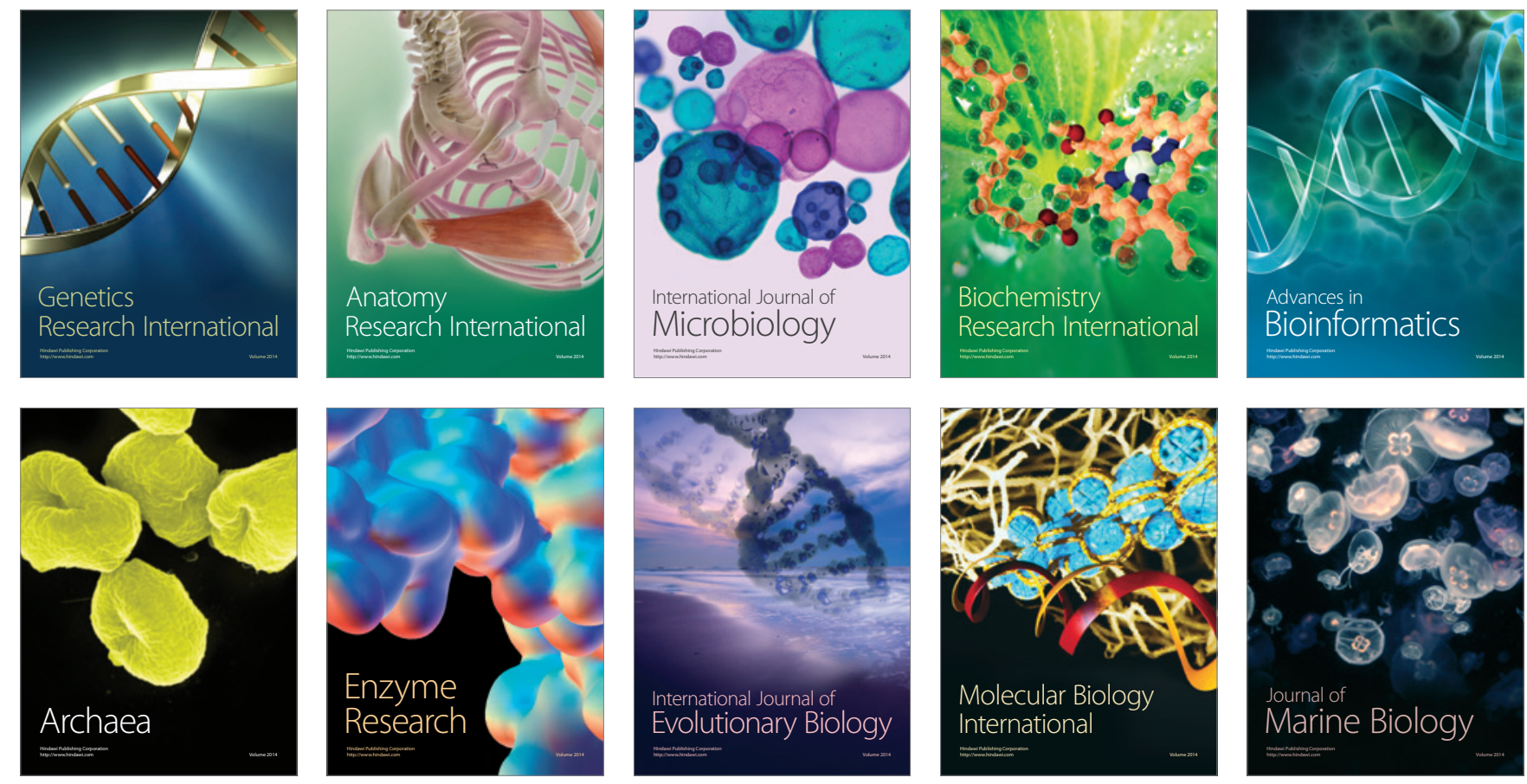